\title{
Differential effects of amount of feeding on cell proliferation and progesterone production in response to gonadotrophins and insulin- like growth factor I by ovarian granulosa cells of broiler breeder chickens selected for fatness or leanness
}

\author{
O. M. Onagbesan ${ }^{1}$, E. Decuypere ${ }^{1}$, F. Leenstra ${ }^{2}$ and D. A. Ehlhardt ${ }^{2}$ \\ ${ }^{1}$ Laboratory for Physiology and Immunology of Domestic Animals, Catholic University of Leuven, Kardinaal Mercierlaan 92, B-3001 \\ Heverlee, Belgium; and ${ }^{2}$ DLO-Institute for Animal Science and Health, Lelystad, The Netherlands
}

\begin{abstract}
Strain differences in reproductive performance were demonstrated between broiler breeder female chickens selected for growth (GL line) or for food conversion efficiency (FC line) and the improvement in reproductive performance due to feed restriction also differed significantly. Feed allowance effects on the maturation of ovarian follicles, the incidence of atresia and egg production differed between the two lines exposed to similar feeding protocols. Feed restriction reduced body weights significantly and to a similar extent in both GL and FC lines. The number of normal and atretic yellow follicles was significantly higher under ad libitum feeding and in GL line than it was in the FC line. In both lines, feed restriction decreased multiple ovulation and increased egg production. In culture, granulosa cells from the three largest follicles (F1, F2 and F3) increased progesterone production in response to $\mathrm{LH}, \mathrm{FSH}$ and insulin-like growth factor I but responses were different between the GL and FC lines fed either ad libitum or restricted diets. Granulosa cells from the two or three largest follicles in GL and FC (ad libitum) lines produced similar amounts of progesterone in response to LH, FSH and insulin-like growth factor I whereas, in restricted birds, the progesterone production was of the rank order F1 > F2 > F3 in both lines. The responsiveness of the GL line fed ad libitum was higher for LH than for either FSH or insulin-like growth factor I but in the GL line fed a restricted diet, it was high for all the hormones. In the FC line, responses to LH, FSH or insulin-like growth factor I were high in ad libitum-fed birds, but low in birds fed a restricted diet for all hormones. Insulin-like growth factor I combined with LH or FSH significantly increased the progesterone production of granulosa cells from birds fed restricted diets of both lines and this effect increased with increasing follicular size. There was a lack of interaction between insulin-like growth factor I and LH or FSH in the regulation of progesterone production by birds of both lines fed ad libitum. Insulin-like growth factor alone or in combination with LH or FSH increased granulosa cell proliferation in birds fed ad libitum more than it did in birds fed restricted diets. The greater proliferation rate of granulosa cells of chickens fed ad libitum, in response to insulin-like growth factor I alone or in combination with gonadotrophins, leading to the simultaneous differentiation of two or three large follicles with high progesterone production in response to LH or insulin-like growth factor I, accelerates the rate of maturation of follicles. This may also be the major cause of erratic and multiple ovulations in broiler breeder female chickens fed ad libitum. In conclusion, insulin-like growth factor $\mathrm{I}$, alone or in combination with LH or FSH, is an important component in the control mechanisms for follicular development in broiler breeder hens. It is this component that is targeted by feed allowance and inadvertently altered by selection for growth.
\end{abstract}

\section{Introduction}

In broiler chickens, there is a strong negative correlation between body weight and reproductive performance. Although the broiler breeder chicken ovary often contains Received 12 June 1998. twice as many yellow follicles as the egg-type chicken ovary, egg production is relatively poor (Jaaps and Muir, 1968; Hocking et al., 1987; Yu et al., 1992a). This low egg production is further exacerbated by feeding ad libitum which results in excessive weight gain. Thus, attempts to improve reproductive performance in broiler hens have concentrated Downloaded from Bioscientifica.com at $04 / 26 / 2023$ 02:12:57PM 
on severely limiting body weight during rearing and breeding. The major causes of the inherently low egg production in birds fed ad libitum have been identified as atresia of yellow follicles, erratic and multiple ovulations, which could be internal or result in soft, thin, poorly shelled or double-yolked eggs (Yu et al., 1992b, Hocking, 1993). These are the consequences of excessive follicular recruitment from the white follicles into the heirarchy of yellow follicles (Hocking et al., 1987, 1989; Waddington and Hocking 1993).

Feed restriction has been shown to reduce body weight and produce a concomitant decrease in ovary weight, number of yellow follicles and atresia, resulting in improved reproductive performance (Hocking et al., 1989; Katanbaf et al., 1989). It is still not clear how increased food intake in poultry results in excessive recruitment into the hierarchy of yellow follicles such that many of them are at a similar physiological state. In birds fed ad libitum, the largest and second largest follicles produce similar amounts of progesterone and androstenedione whereas, in birds fed a restricted diet, only the largest follicle, which is destined to ovulate next, secretes any significant amount of progesterone (Yu at al., 1992a). Johnson et al. (1985) showed that injections of pregnant mares' serum gonadotrophin increase the number of yellow follicles in hens. Armstrong (1994) and Hocking and McCormack (1995) postulated that changes in the sensitivity of follicles to gonadotrophins during maturation could explain the differential follicular recruitment between broilers and layertype chickens fed ad libitum or restricted diets. These reports directly implicate gonadotrophins in the regulation of follicle growth and differentiation but do not fully explain the differential in the incidence of atresia or erratic and multiple ovulations between birds fed ad libitum and restricted diets. However, it is known that the activity of gonadotrophins in the follicles is largely modulated by intraovarian growth factors (Peddie et al., 1994; Onagbesan and Peddie, 1995). Differential egg production by birds fed ad libitum or restricted diets has also been related to plasma insulin-like growth factor I (IGF-I) concentrations which are higher in restricted chickens (Hocking et al., 1994).

The purpose of the present study was to probe further into the underlying mechanisms by which feeding allowance modifies follicular distribution and the endocrine profile of the hierarchy of follicles in broiler breeder chickens. The effects of ad libitum and restricted feeding on body weight, follicle distribution, atresia and in vitro responsiveness of cultured follicular cells to LH, FSH and IGF-I were examined. These parameters were compared between two lines of broiler breeder chickens selected either for growth (GL) or for feed conversion (FC). Owing to correlated selection responses, GL line chickens are significantly fatter than FC line chickens. The history of the selection of these lines is detailed in reports by Leenstra et al. (1986) and Leenstra and Pit (1987).

\section{Materials and Methods}

\section{Animals}

Broiler breeder hen lines selected for body weight (GL) or for food conversion (FC) were used. Each line of chickens was divided into two groups and each half was reared from 2 weeks of age either on ad libitum feeding (GLA or FCA) or restricted to $50 \%$ of the ad libitum feeding of the respective lines (GLR or FCR) on the basis of body weights. Conventional pelleted starter (11.7 MJ metabolizable energy $\mathrm{kg}^{-1}, 18.5 \%$ crude protein) and grower (11.3 MJ metabolizable energy kg ${ }^{-1}, 15 \%$ crude protein) diets were fed to birds up to 20 weeks of age. During rearing, chickens were kept in groups on floor pens littered with wood shavings. Birds fed ad libitum were allowed access to water ad libitum. In restricted pens, the water was turned off at noon. The environmental temperature of pens was $33^{\circ} \mathrm{C}$ for days 1 and 2 of the study and, thereafter, was reduced by $1.5^{\circ} \mathrm{C}$ per week down to $20^{\circ} \mathrm{C}$, and lighting was maintained at $14 \mathrm{~h}$ light: $10 \mathrm{~h}$ dark from 19 weeks of age.

During lay, a layer mash (11.5 MJ metabolizable energy $\mathrm{kg}^{-1}, 17 \%$ crude protein) was fed ad libitum to the GLA and FCA groups and 75\% of these portions were fed to the GLR and FCR groups. At point of lay, birds were individually caged to monitor laying performance.

\section{Determination of body weights, number of normal or atretic yellow follicles and egg production}

Once a week between weeks 35 and 40 , four chickens were selected from each of the groups (GLA, GLR, FCA and FCR) and weighed. Birds were killed by cervical dislocation and the ovaries were removed. Yellow follicles were excised, counted and classified as either normal or atretic. The incidence of internal laying was also recorded. Egg laying by individual birds was recorded daily. The percentage egg production was determined in all birds of each group (a total of 48 hens) kept for laying performance, including those that were not laying regularly.

\section{Experiments in vitro}

Laying hens aged 35-40 weeks were used. Two or three hens from each group were selected $2-4 \mathrm{~h}$ after oviposition, weighed and killed by cervical dislocation. Ovaries were removed, weighed and the yellow follicles were excised. The three largest follicles were then used for granulosa cell preparation and culture.

\section{Granulosa cell isolation and culture}

Granulosa tissues were collected from F1, F2 and F3 follicles as described by Gilbert et al. (1977). Cells were dispersed and pooled from each category of follicle from the two hens and cell density was determined by measuring the DNA in aliquots using the method of Labarca and Paigen (1980) in which $1 \mu \mathrm{g}$ DNA $=10^{5}$ cells. Cell viability, assessed by the Trypan blue method, was always $>90 \%$. Cells were plated at a concentration of 10000 viable cells per well in 24well plastic plates (Corning Inc., Corning, NY) and cultured in M199 supplemented with $2 \mathrm{mmol}$ glutamine ${ }^{-1}, 40 \mathrm{mmol}$ 
sodium bicarbonate $1^{-1}, 1 \%(\mathrm{v} / \mathrm{v})$ PSA (antibiotic-antimycotic solution) and $5 \%$ charcoal-stripped fetal calf serum (FCS) for $48 \mathrm{~h}$ in a humidified atmosphere of $5 \% \mathrm{CO}_{2}$ in air at $37^{\circ} \mathrm{C}$ to establish cultures. After this first period of culture, the medium was discarded and monolayer cells washed with phenol-free Hank's balanced salt solution (HBSS) and then cultured for a further $48 \mathrm{~h}$, according to the experimental protocol, in serum-free M199 supplemented with $2 \mathrm{mmol}$ glutamine $\mathrm{l}^{-1}$, sodium bicarbonate, $1 \%$ PSA, $6.25 \mu \mathrm{g}$ transferrin $\mathrm{ml}^{-1}, 5 \mathrm{ng}$ selenium $\mathrm{ml}^{-1}$ and $0.1 \%$ BSA. At the end of the first $48 \mathrm{~h}$ of culture, a set of plates was withdrawn and washed to determine the number of cells attached and viable by measuring the DNA content and Trypan blue reaction. Cell attachment was often variable among follicle sizes and experiments. The amount of DNA per cell number at this point was taken as the time zero $\left(t^{\circ}\right)$ value for all cultures. All additions of test hormones were made in the second period of culture of $48 \mathrm{~h}$.

\section{Effect of LH, FSH or IGF-I on progesterone production}

The dose-dependent response of the cells to $\mathrm{LH}, \mathrm{FSH}$ or IGF-I was tested by the addition of increasing concentrations of the separate hormones $\left(0-100 \mathrm{ng} \mathrm{ml}^{-1}\right)$ to cells cultured from the F1, F2 or F3 follicles collected from the different groups. Cells were also cultured with IGF-I with or without LH or FSH to determine the interaction between both hormones on progesterone production. The total incubation volume in all experiments was always $500 \mu \mathrm{l}$ per well. At the end of the incubation period, the medium was collected and stored at $-20^{\circ} \mathrm{C}$ until assayed for progesterone by radioimmunoassay. At the end of the experiments, the DNA contents of wells were measured to determine the final number of cells in each well. This was used to correct progesterone production depending on the number of cells per well, since cell attachment to plates and the rate of proliferation varied among follicle sizes, time in culture and different experiments.

\section{Effect of LH, FSH or IGF-I on granulosa cell proliferation}

Separate cultures of granulosa cells prepared from the F1, F2 and F3 follicles were made as described above. Increasing concentrations of LH, FSH, or IGF-I were added to cultures and incubated for $48 \mathrm{~h}$. Plates were washed and the DNA content of wells was measured to assess cell proliferation during the culture period.

\section{DNAassay}

Cultures for the determination of DNA were washed with phenol-free HBSS. The cells were disaggregated with $200 \mu \mathrm{l}$ trypsin-EDTA in TNE buffer $\left(10 \mathrm{mmol}\right.$ Tris $\mathrm{l}^{-1}, 1 \mathrm{mmol}$ EDTA $\mathrm{l}^{-1}, 2 \mathrm{~mol} \mathrm{NaCl}^{-1}, \mathrm{pH} \mathrm{7.4)}$ followed by sonication. The DNA in aliquots of the lysate was determined by the method of Labarca and Paigen (1980) using calf thymus DNA as standard and H33258 (bisbenzimide) as fluorogen. The DNA was quantified on the TKO 100 mini fluorometer (Hoeffer Scientific Instruments, San Francisco, CA).

\section{Progesterone assay}

Progesterone concentration in the medium was determined without extraction, by radioimmunoassay using a commercial kit (ICN Biomedicals Inc., Costa Mesa, CA). The crossreactivities of the antiserum in the kit with other ligands are $20 \alpha$-dihydroprogesterone $5.46 \%$, desoxycorticosterone $3.80 \%$ and $<1 \%$ for other steroids. The intra-assay and interassay coefficients of variation were $7.8 \%$ and $12.0 \%$, respectively.

\section{Statistical analysis}

In the experiments in vitro, because of variations in cell attachment to plates in the different experiments and differences in the proliferation rate among follicle sizes, the results of DNA synthesis (which were measured as $\mu \mathrm{g}$ DNA per well) have been expressed as percentage increase in DNA per well over untreated control cultures. For the same reason, the DNA content of culture wells for progesterone were measured to estimate the final cell numbers in the wells such that all data on progesterone secretion were corrected and expressed as ng $\mu g^{-1}$ DNA. Results are expressed as means \pm SEM of four or five experiments, each with four replicates. Means were compared by ANOVA followed by Duncan's multiple range test (General Linear Models procedure, SAS) or Student's $t$ test to determine significance. $P<0.05$ was considered significant.

\section{Results}

Effects of food allowance on body weight, number of normal and atretic yellow follicles, incidence of internal laying and egg production

Both lines of chickens fed ad libitum had similar body weights and restricted feeding reduced body weights significantly in both groups to a similar extent (Fig. 1a). There were breed differences in the number of yellow follicles in the ovary. GLA birds tended to have more yellow (normal plus atretic) follicles than did the FCA birds (Fig. 1b). Restricted feeding significantly decreased the average number of yellow follicles in both lines. Furthermore, GLR chickens had a similar average number of yellow follicles as FCA chickens. The incidence of atresia in yellow follicles in both lines is shown (Fig. 1c). GLA birds showed the highest incidence of atresia. Comparatively, this was significantly lower than it was in the FCA birds, indicating a significant breed difference. Restricted diet significantly reduced the occurrence of atresia in yellow follicles of both lines. Atretic follicles were not found in any FCR birds slaughtered.

Egg production also showed breed differences and differences due to feeding regimen. Percentage egg production (for 64 hen days between weeks 31 and 38) was 

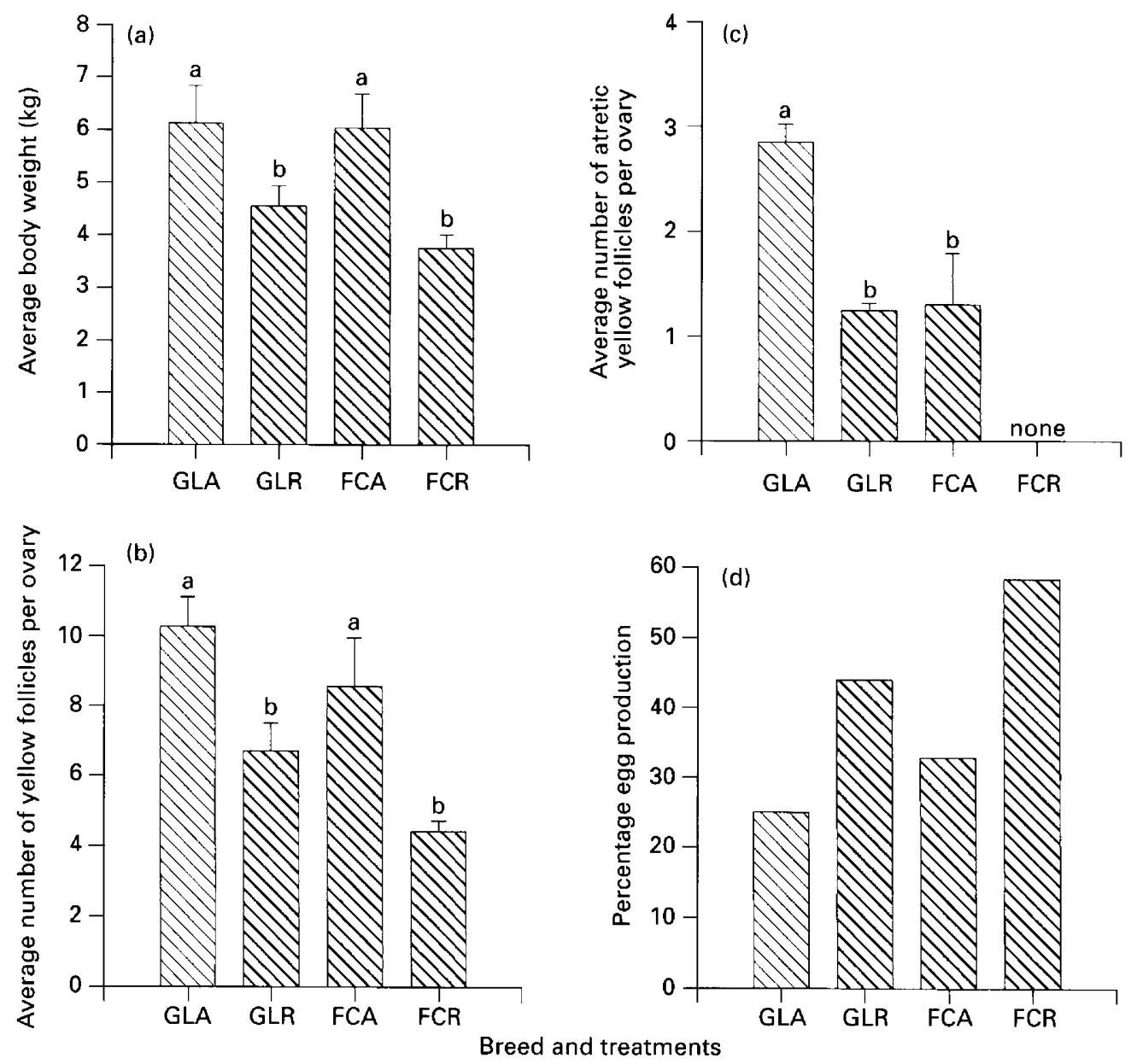

Fig. 1. Average body weight (a), number of normal (b) or atretic yellow follicles (c), and egg production (d) by broiler breeder female chickens selected for growth (GL line) or for food conversion efficiency (FC line) fed ad libitum (GLA or FCA) or restricted diets (GLR or FCR) during rearing and breeding. Data on egg production are presented as percentage egg production for 64 hen days (weeks 31-38) and represent production by all birds kept for egg laying performance for each group. Data were analysed by ANOVA followed by a multiple range test. Significant differences between groups are indicated by different letters, $P<0.05$.

low in both GLA and FCA birds. Feed restriction increased percentage egg production by $25.49 \%(32.81 \%$ in the FCA and $58.3 \%$ in the FCR birds) in the FCR and by $19 \%$ in the GLR birds ( $25 \%$ in GLA and $44 \%$ in the GLR birds). Internal ovulation was a common occurrence $(100 \%)$ in both groups that were fed ad libitum and ovulated follicles were found in the abdominal cavity of these birds. This incidence was significantly reduced (to $30 \%$ of birds) in GLR birds and was completely absent in FCR birds.

\section{Effect of LH on progesterone production}

There was a significant interaction between the strain of bird and feeding regimen applied $(\mathrm{S} \times \mathrm{F})$ between the groups within follicles in their responsiveness to LH stimulation $(P<0.05)$. LH showed differential stimulation of progesterone production between GL and FC lines, depending on the feeding regimen.
In general, $\mathrm{LH}$ increased progesterone production in a dose-dependent manner in all groups (GLA, GLR, FCA and FCR) (Fig. 2). F1, F2 and F3 granulosa cells of the GLA chickens (Fig. 2a) showed similar responsiveness to increasing $\mathrm{LH}$ doses up to $10 \mathrm{ng} \mathrm{ml}^{-1}$. At higher doses of 25 and $50 \mathrm{ng} \mathrm{ml}^{-1} \mathrm{LH}$, both the F1 and F2 cells still secreted similar amounts of progesterone but the production from $\mathrm{F} 3$ cells was lower. Applying a feeding restriction to the GL chickens (GLR) significantly changed the profile of progesterone production by the F1, F2 and F3 cells in response to $\mathrm{LH}$ (Fig. 2b). Progesterone production was significantly different among the F1, F2 and F3 cells at 1, 10, 25 and $50 \mathrm{ng} \mathrm{LH} \mathrm{ml}^{-1}$ : the F1 cells produced more than the F2 cells, which produced more than the F3 cells. Production of progesterone in response to most doses of LH applied was similar in the F1 cells in both GLA and GLR birds but was significantly higher in the F2 and F3 cells of GLA birds compared with similar follicles in the GLR birds.

The effect of increasing the doses of $\mathrm{LH}$ on progesterone 

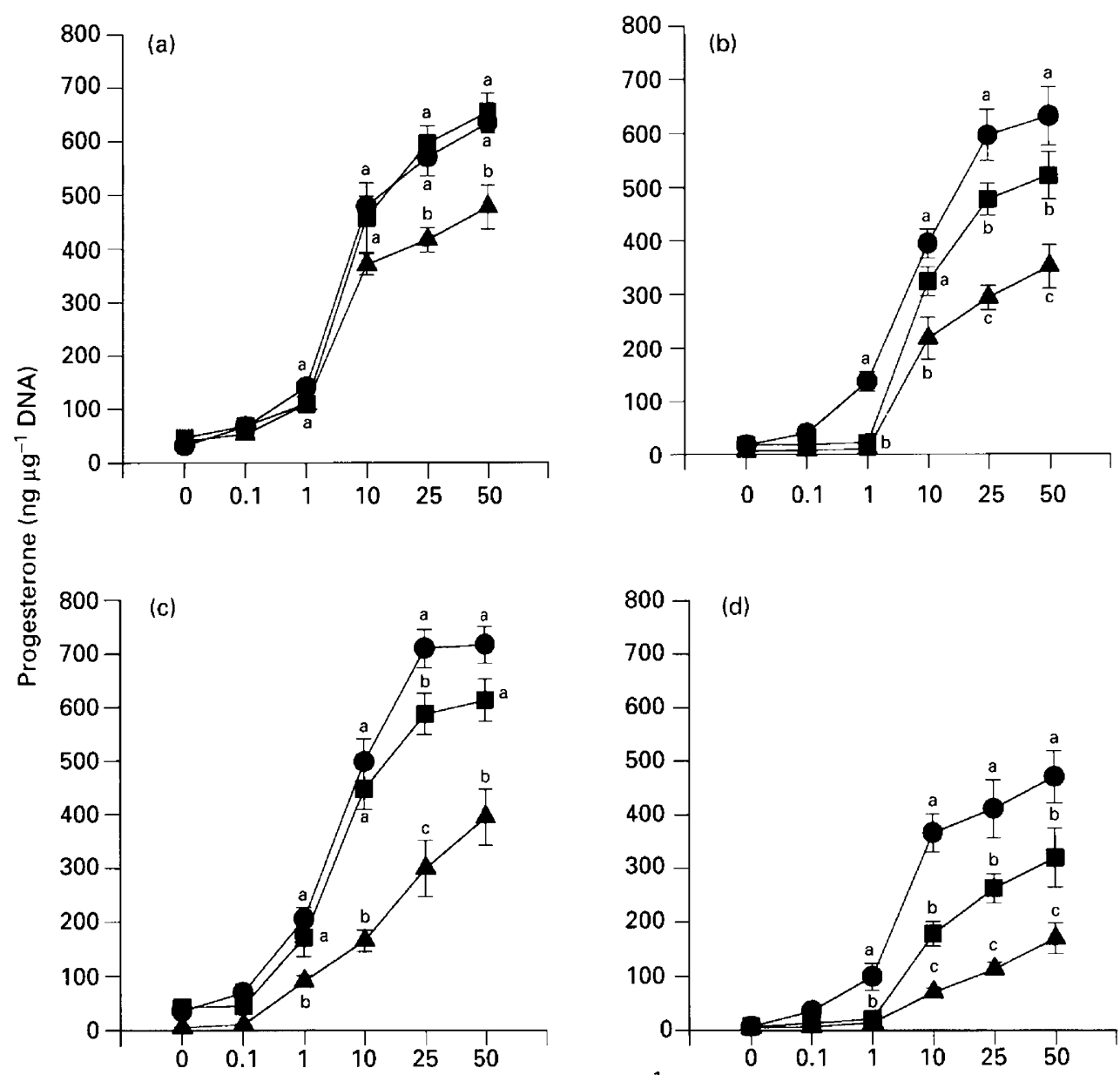

$\mathrm{LH}\left(\mathrm{ng} \mathrm{ml} \mathrm{m}^{-1}\right.$ )

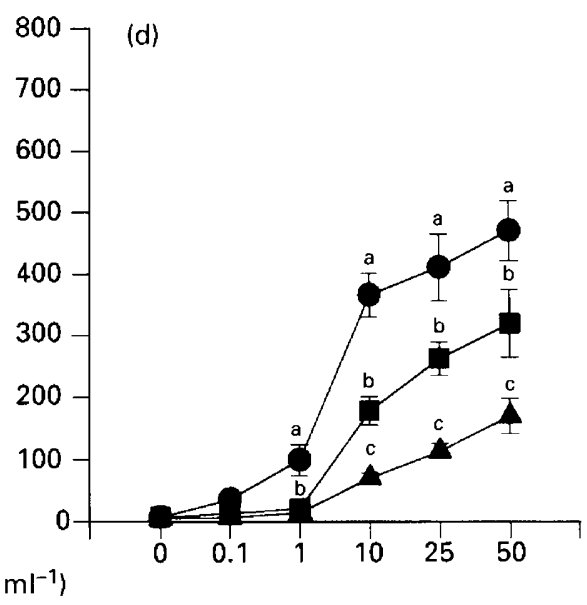

Fig. 2. Effect of LH on progesterone production by cultured granulosa cells from the three largest ovarian follicles (F1, $\mathbf{O}$;, $\mathbf{\square}$; and F3, $\mathbf{\Delta}$ ) of broiler breeder female chickens selected for growth (GL line) or for food conversion efficiency (FC line) fed ad libitum (GLA (a) or FCA (c)) or restricted diets (GLR (b) or FCR (d)). Cells were cultured with LH at different doses in serum-free medium for $48 \mathrm{~h}$. Data points are means \pm SEM of experiments repeated four or five times, each with four replicate wells. Data were analysed by ANOVA followed by a multiple range test. Significant differences between follicle sizes at each dose of $\mathrm{LH}$ are denoted by different letters, $P<0.05$.

production by granulosa cells of FCA birds is shown (Fig. 2c). Again, progesterone production of F1 and F2 cells in response to $\mathrm{LH}$ was similar up to $10 \mathrm{ng} \mathrm{LH} \mathrm{ml}^{-1}$, but lower for F2 at 25 and $50 \mathrm{ng} \mathrm{LH} \mathrm{ml}^{-1}$. Secretion by F3 cells was significantly lower at all doses. In FCR birds (Fig. 2d), progesterone production significantly differed among the $\mathrm{F} 1$, F2 and F3 cells at all doses, with the F1 cells producing more than the F2 cells, which produced more than the F3 cells. Progesterone production at basal concentration or in response to all LH doses was significantly higher for the FCA than it was for the FCR birds.

\section{Effect of FSH on progesterone production}

Among the four groups, there was a significant interaction of strain and feeding level $(\mathrm{S} \times \mathrm{F} ; P<0.01)$
FSH increased progesterone production by cells of all the follicles in the GLA, GLR, FCA and the FCR groups in a dose-dependent manner (Fig. 3). There were no significant differences in progesterone production by granulosa cells from the $F 1, F 2$ and $F 3$ follicles of the GLA group, in response to increasing doses of FSH (Fig. 3a). In the GLR group (Fig. $3 b)$, progesterone production was significantly different between the F1 and the F2 cells at 10, 25 and $50 \mathrm{ng} \mathrm{FSH} \mathrm{ml}^{-1}$ but there was no difference between the F2 and F3 cells. However, progesterone production by cells in response to 25 and $50 \mathrm{ng} \mathrm{FSH} \mathrm{ml}^{-1}$ was significantly higher in GLR birds than it was in GLA birds.

Progesterone production by cells of FCA birds (Fig. 3c) was significantly different among follicles at all doses of $\mathrm{FSH}$; the production by F1 cells was highest, followed by the F2 and F3 cells. In FCR birds (Fig. 3d), progesterone production also showed significant differences among 

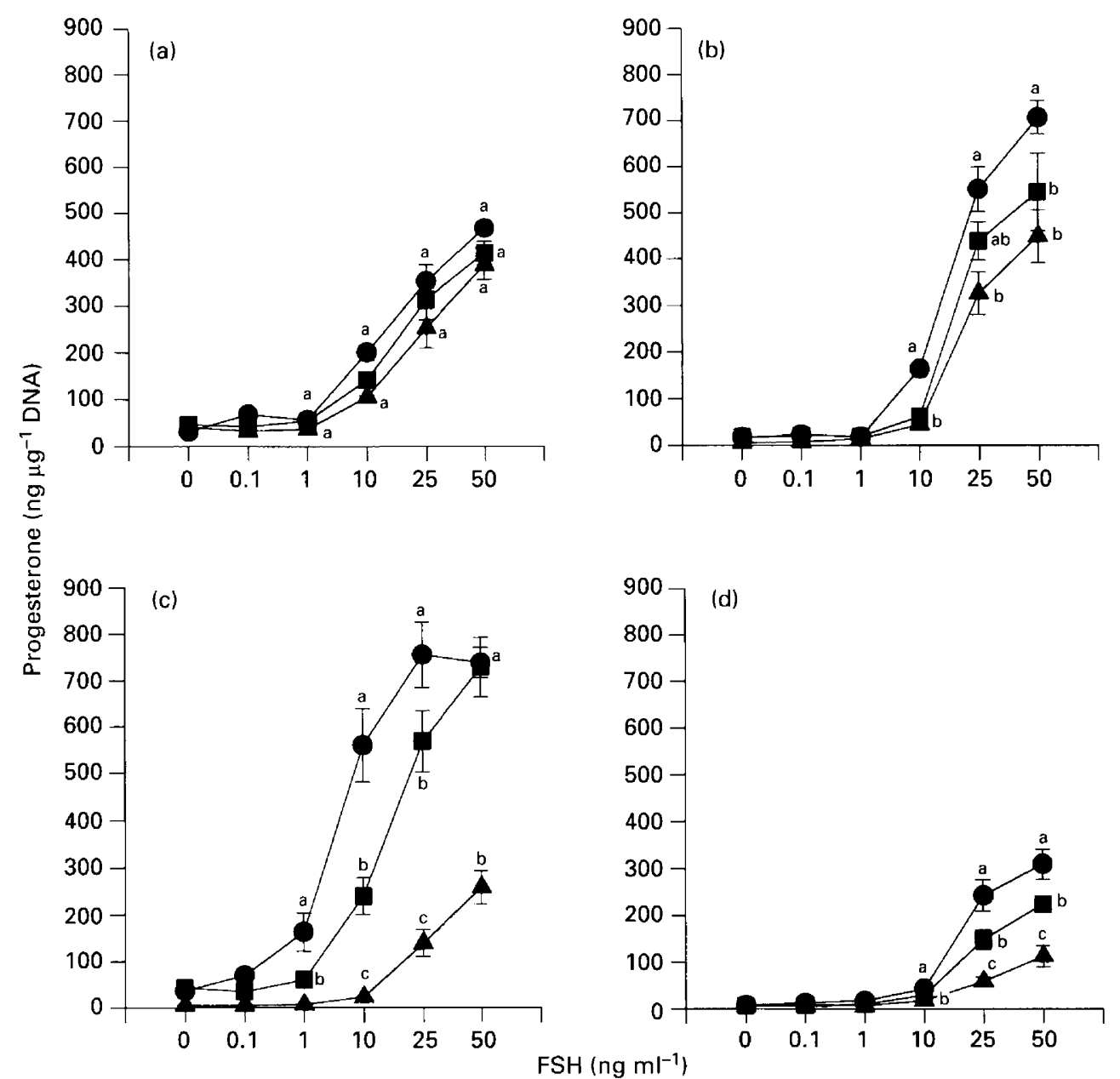

Fig. 3. Effect of FSH on progesterone production by cultured granulosa cells from the three largest ovarian follicles $(\mathrm{F} 1, \mathbf{O} ; \mathrm{F} 2, \mathbf{\square}$; and F3, $\mathbf{\Delta}$ ) of broiler breeder female chickens selected for growth (GL line) or for food conversion efficiency (FC line) fed ad libitum (GLA (a) or FCA (c)) or restricted diets (GLR (b) or FCR (d)). Cells were cultured with FSH at different doses in serum-free medium for $48 \mathrm{~h}$. Data points are means \pm SEM of experiments repeated four or five times, each with four replicate wells. Data were analysed by ANOVA followed by a multiple range test. Significant differences between follicle sizes at each dose of LH are denoted by different letters, $P<0.05$.

follicles at 10,25 and $50 \mathrm{ng} \mathrm{FSH} \mathrm{ml}^{-1}$. Progesterone secretion increased from the F3 to the F1 cells.

In contrast to the situation in the GL line, basal and FSHstimulated progesterone production by granulosa cells was significantly higher in FCA birds than it was in FCR birds.

\section{Effect of IGF-I on progesterone production}

Comparison among the four groups showed an interaction between strain and feeding regimen on progesterone production by IGF-I within follicles $(\mathrm{S} \times \mathrm{F}$; $P<0.01)$.

IGF-I stimulated progesterone production in a dosedependent manner in all groups (Fig. 4). The maximum effective dose in all groups was $10 \mathrm{ng}$ IGF-I ml-1, beyond which progesterone production decreased. In GLA chickens (Fig. 4a), progesterone production in response to IGF-I was similar in the F1, F2 and F3 cell cultures at all doses except $100 \mathrm{ng}^{\mathrm{IGF}-\mathrm{I} \mathrm{ml}}{ }^{-1}$, at which the F3 showed a relatively lower response. However, in GLR birds (Fig 4b), progesterone production in response to IGF-I was significantly different between the F1 and both F2 and F3 cells at all doses. The F2 cells showed significantly higher progesterone production than the F3 cells at 1 and $10 \mathrm{ng}$ IGF-I ml ${ }^{-1}$ only. At all doses of IGF-I, the GLR granulosa cells produced significantly higher amounts of progesterone than did the GLA cells. Granulosa cells cultured from the F1 and F2 follicles of the FCA (Fig. 4c) produced similar amounts of progesterone at all doses except $10 \mathrm{ng}$ IGF-I ml-1. However, progesterone production by the $\mathrm{F} 3$ cells was significantly lower than that of the F1 and F2 cells. Progesterone production by cells of the F1, F2 and F3 


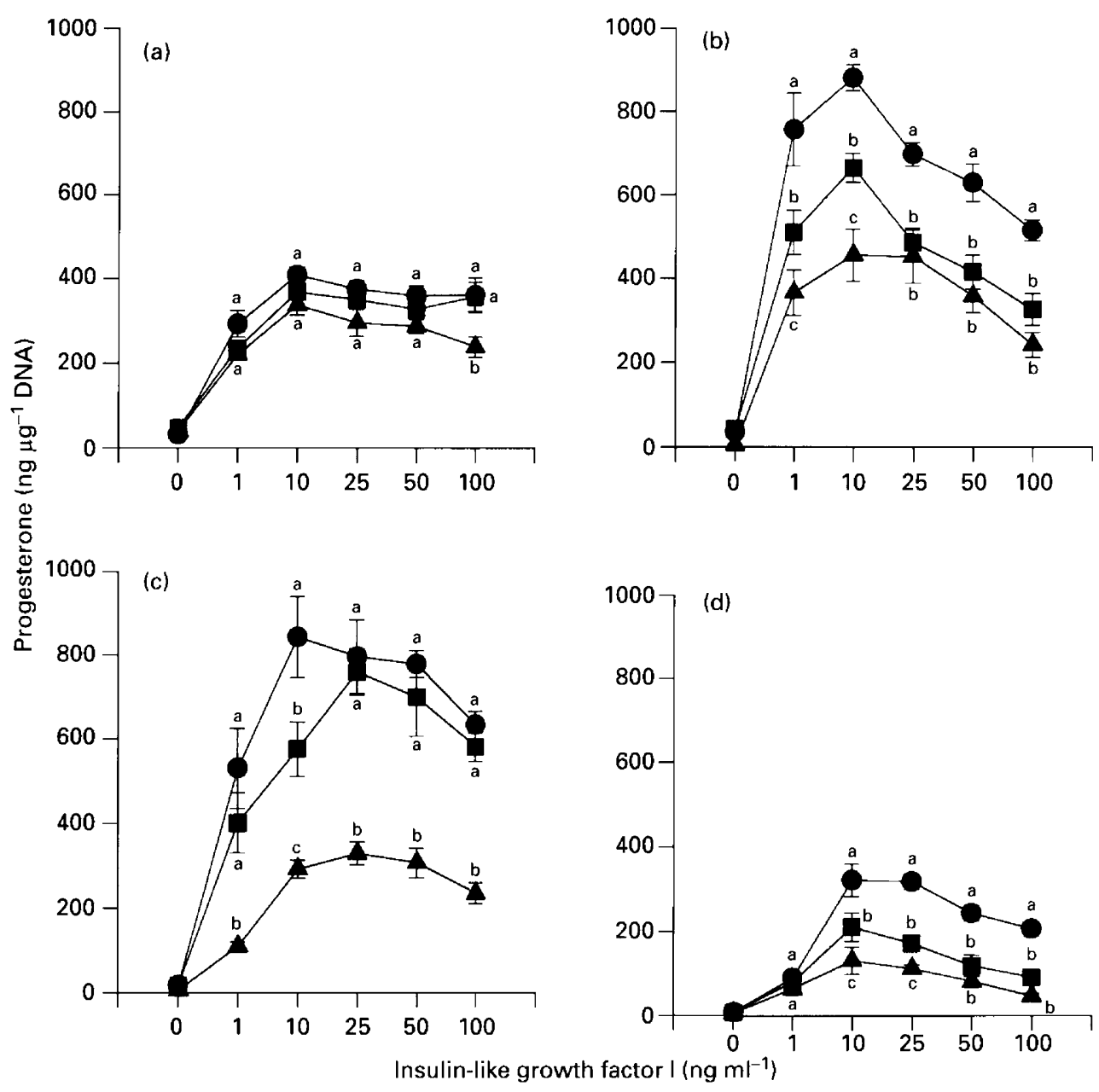

Fig. 4. Effect of insulin-like growth factor I (IGF-I) on progesterone production by cultured granulosa cells from the three largest ovarian follicles (F1, $; F 2$, $\mathbf{a}$; and F3, $\mathbf{\Delta}$ ) of broiler breeder female chickens selected for growth (GL line) or for food conversion efficiency (FC line) fed ad libitum (GLA (a) or FCA (c)) or restricted diets (GLR (b) or FCR (d)). Cells were cultured with IGF-I at different doses in serumfree medium for $48 \mathrm{~h}$. Data points are means \pm SEM of experiments repeated four or five times, each with four replicate wells. Data were analysed by ANOVA followed by a multiple range test. Significant differences between follicle sizes at each dose of LH are denoted by different letters, $P<0.05$.

follicles obtained from the FCR birds (Fig. 4d) was significantly different at all doses. The F1 culture medium had the highest and the F3 culture medium the lowest progesterone content. In contrast to the GL line, the production of progesterone in response to IGF-I by the follicles of the FC line was significantly lower in the FCR than in the FCA birds, at all doses.

\section{Effect of IGF-I in combination with $\mathrm{LH}$ or FSH on progesterone production}

The effect of IGF-I $\left(1 \mathrm{ng} \mathrm{ml}^{-1}\right)$ alone and in combination with $\mathrm{LH}$ at 10 or $25 \mathrm{ng} \mathrm{LH} \mathrm{ml}^{-1}$ on progesterone secretion from cultured granulosa cells of F1, F2 and F3 follicles from GLA, GLR, FCA and FCR chickens is shown (Fig. 5). IGF-I significantly increased progesterone production by these cells in all categories of chicken. However, cells from the different groups of chickens showed differential responsiveness. In both F1 and F2 cells, restricted birds of the GL line showed significantly higher progesterone production in response to $1 \mathrm{ng}$ IGF-I ml ${ }^{-1}$ whereas, in the FC line, the FCA birds showed higher production than the FCR birds. However, in F3 cells, both ad libitum groups were more responsive to IGFI than were the restricted groups. LH at 10 or $25 \mathrm{ng} \mathrm{ml}^{-1}$ doses also significantly enhanced progesterone production in all categories of follicular cells and groups of chicken. Again, there was differential responsiveness among follicular hierarchy, breed and feeding groups. The F1 and F2 cells of GLA and GLR responded similarly to 10 and $25 \mathrm{ng}$ $\mathrm{LH} \mathrm{ml}{ }^{-1}$, whereas progesterone production by FCR cells was significantly lower than that of cells from the FCA chickens. 

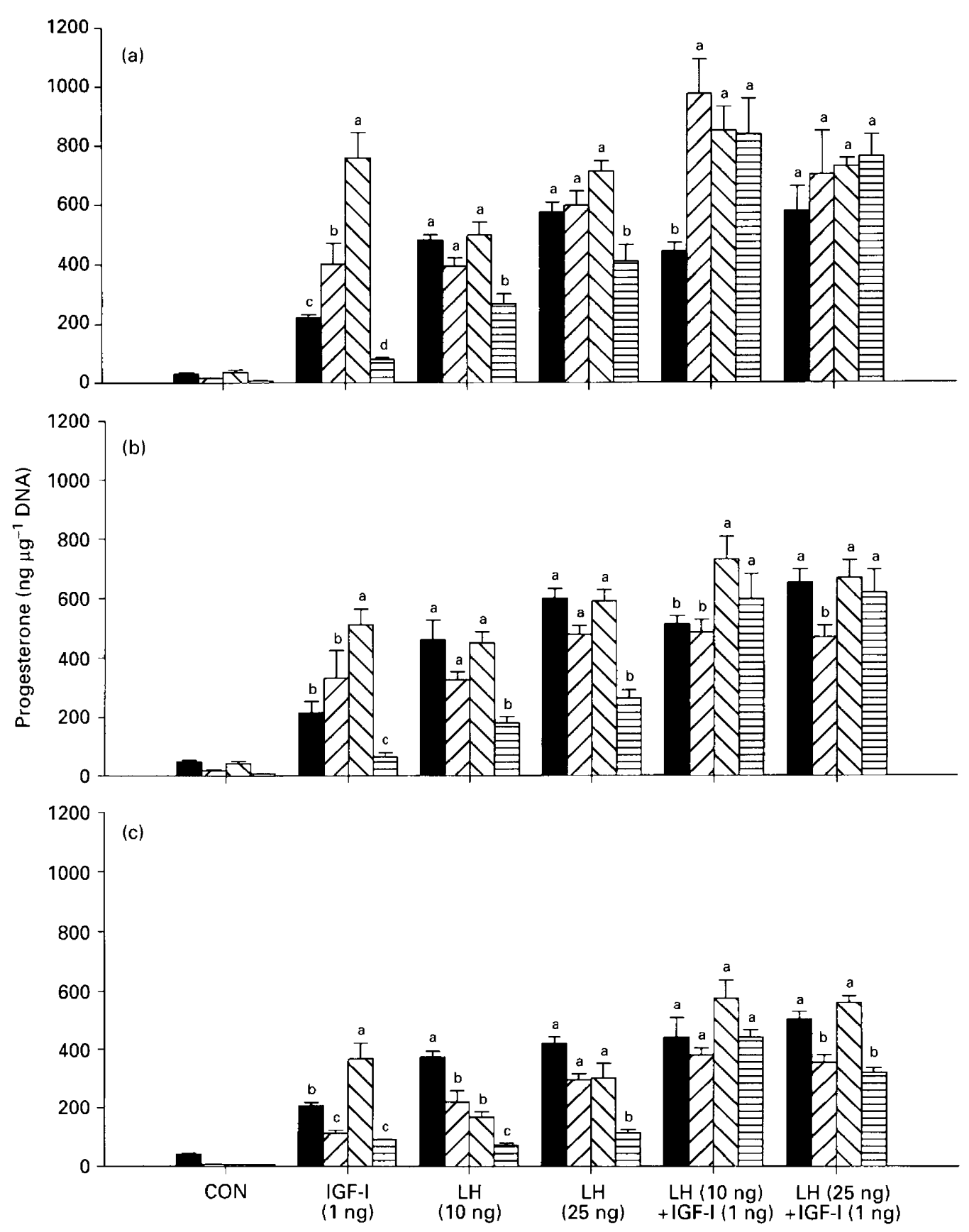

Fig. 5. Interaction of insulin-like growth factor I (IGF-I; $1 \mathrm{ng} \mathrm{ml}^{-1}$ ) and LH (10 and $25 \mathrm{ng} \mathrm{ml}^{-1}$ ) on progesterone production by cultured granulosa cells from the three largest ovarian follicles: ((a) F1, (b) F2 and (c) F3) from broiler breeder female chickens selected for growth (GL line) or for food conversion efficiency (FC line) fed ad libitum (GLA $(\square)$ or FCA $(\Delta)$ ) or restricted diets (GLR $(\square)$ or FCR (曰)). Cells were cultured either with IGF-I or LH alone or in combination in serum-free medium for $48 \mathrm{~h}$. Data are means \pm SEM of experiments repeated four or five times, each with four replicate wells. Data were analysed by ANOVA followed by a multiple range test. Significant differences between lines and feeding groups within each treatment are denoted by different letters, $P<0.05 . \mathrm{CON}$, control.

The F3 cells of both groups fed ad libitum secreted more progesterone in response to LH at doses of 10 and $25 \mathrm{ng} \mathrm{ml}^{-1}$ than did the restricted diet groups.

The addition of IGF-I $\left(1 \mathrm{ng} \mathrm{ml}^{-1}\right)$ to cultures simultaneously with LH significantly enhanced the effect of LH on progesterone production by the cells of restricted but not in the F1 and F2 cells of birds fed ad libitum. This effect was greater in the combination of IGF-I with $10 \mathrm{ng} \mathrm{ml}^{-1} \mathrm{LH}$, and increased with follicular maturation $(\mathrm{F} 1>\mathrm{F} 2>\mathrm{F} 3)$. It was noted that the capacity of the GLA cells to produce 

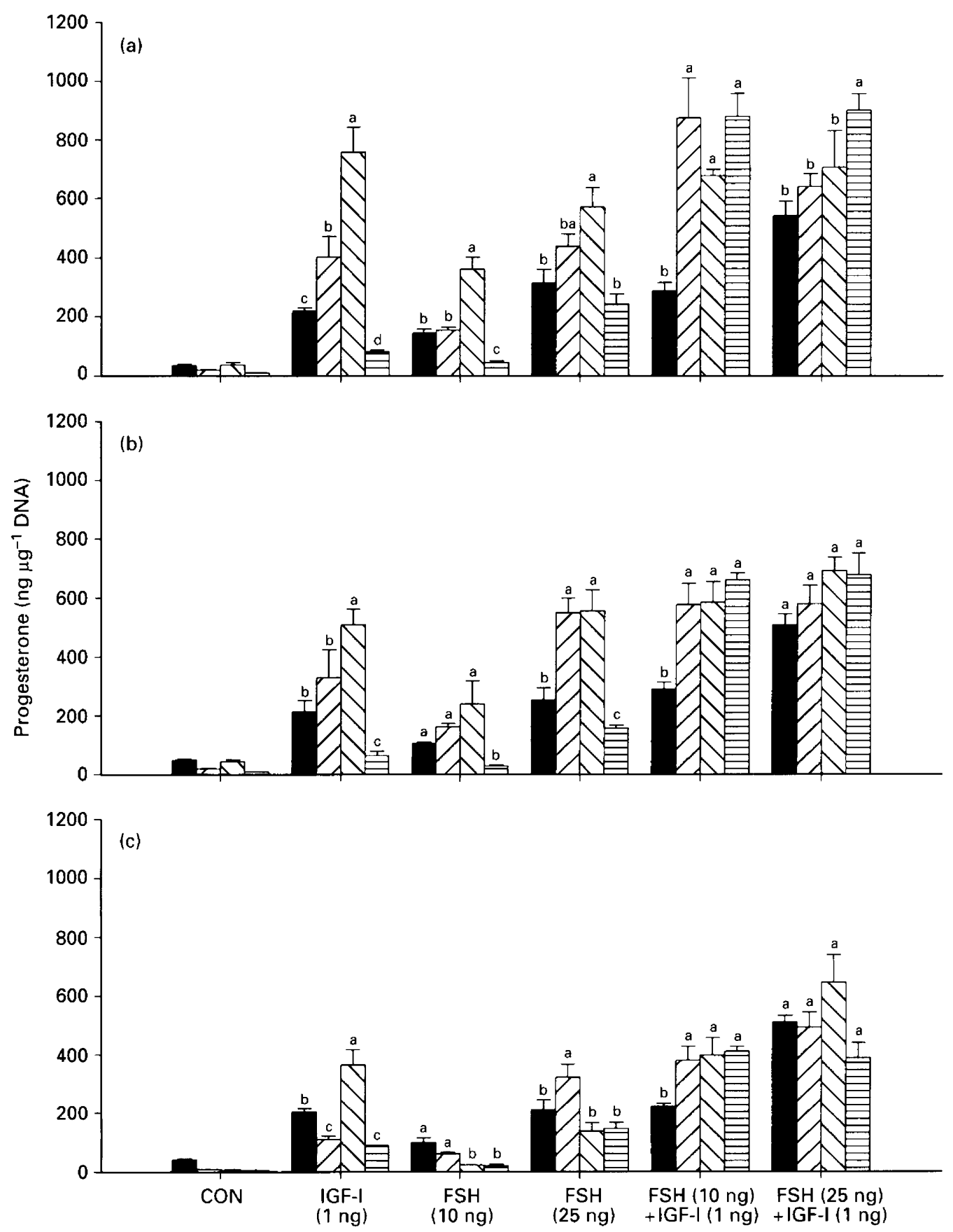

Fig. 6. Interaction of insulin-like growth factor I (IGF-I; $1 \mathrm{ng} \mathrm{m}^{-1}$ ) and FSH $\left(10\right.$ and $25 \mathrm{ng} \mathrm{ml}^{-1}$ ) on progesterone production by cultured granulosa cells from the three largest ovarian follicles: ((a) F1, (b) F2 and (c) F3) from broiler breeder female chickens selected for growth (GL line) or for food conversion efficiency (FC line) fed ad libitum (GLA $(\square)$ or FCA $(\nabla)$ ) or restricted diets (GLR $(\square)$ or FCR $(\boxminus)$ ). Cells were cultured either with IGF-I or FSH alone or in combination in serum-free medium for $48 \mathrm{~h}$. Data are means \pm SEM of experiments repeated four or five times, each with four replicate wells. Data were analysed by ANOVA followed by a multiple range test. Significant differences between lines and feeding groups within each treatment are denoted by different letters, $P<0.05$. CON, control.

progesterone did not differ significantly among the $\mathrm{F} 1, \mathrm{~F} 2$ and F3 in the presence of the combination of IGF-I with LH at all doses.

The effect of the combination of IGF-I ( $\left.1 \mathrm{ng} \mathrm{ml}^{-1}\right)$ with FSH at 10 and $25 \mathrm{ng} \mathrm{ml}^{-1}$ on progesterone production is shown
(Fig. 6). Both doses of FSH increased progesterone production significantly from the cells of all groups of chickens. At $10 \mathrm{ng} \mathrm{FSH} \mathrm{ml}{ }^{-1}$, the granulosa cells of GLA and GLR birds showed no difference in their responsiveness to FSH whereas, at $25 \mathrm{ng} \mathrm{FSH} \mathrm{ml}^{-1}$, feed restriction enhanced 

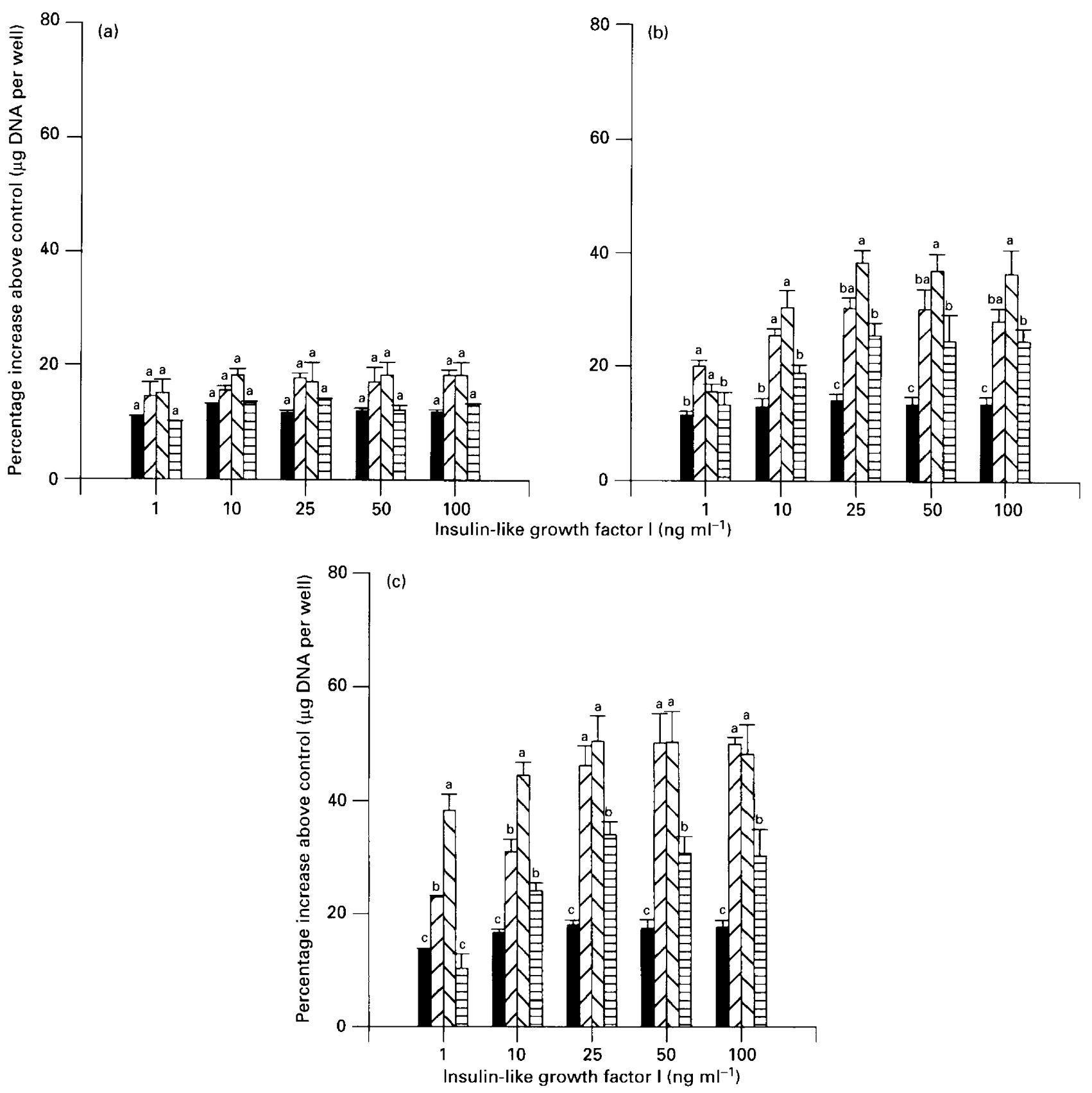

Fig. 7. Effect of insulin-like growth factor I (IGF-I) on DNA synthesis by cultured granulosa cells from the three largest ovarian follicles: ((a) F1, (b) F2 and (c) F3) from broiler breeder female chickens selected for growth (GL line) or for food conversion efficiency (FC line) fed ad libitum (GLA $(\square)$ or FCA $(\nabla)$ ) or restricted diets (GLR $(\nabla)$ or FCR $(\boxminus)$ ). Cells were cultured with IGF-I at different doses in serum-free medium for $48 \mathrm{~h}$. Data are means \pm SEM of experiments repeated four times, each with four replicate wells. Data were analysed by ANOVA followed by a multiple range test. Significant differences between lines and feeding groups at each dose of IGF-I are denoted by different letters, $P<0.05$.

responsiveness to FSH and, thus, progesterone production became significantly higher in FCR than in FCA birds. In the FC group, the cells from the FCA group were more responsive to $\mathrm{FSH}$ alone. However, in the presence of both IGF-I and FSH $\left(10 \mathrm{ng} \mathrm{ml}^{-1}\right)$, progesterone production was significantly enhanced in the restricted diet groups but not in the ad libitum groups (GLR and FCR). Increasing the concentration of FSH to $25 \mathrm{ng} \mathrm{ml}^{-1}$ enhanced progesterone production in GLA but not in FCA birds. The effect of IGF-I with FSH also increased with follicular maturation (F1 > F2 > F3) as was the case with the combination of IGF-I with LH. Progesterone production by GLA in response to either IGF-I or FSH alone or in combination did not differ significantly among F1, $F 2$ and $F 3$ cells. 


\section{Effect of IGF-I on cell proliferation}

The percentage increase in DNA synthesis varied with the strain of chicken, feeding regimen, stage of follicular maturation and dose of IGF-I applied (Fig. 7). DNA synthesis in the F1 granulosa cells of GLA and FCR birds increased by $14 \%$ in response to $1 \mathrm{ng}$ IGF-I ml ${ }^{-1}$. This percentage increase was not different from that found in the GLR and FCA cell cultures $(16 \%)$. Further increase in IGF-I concentration up to $100 \mathrm{ng} \mathrm{ml}^{-1}$ did not improve DNA synthesis significantly in any category of chicken. However, in the F2 and F3 cell cultures, DNA synthesis showed a dose-dependent increase in DNA in the cultures of GLR, FCA and FCR groups but not in that of the GLA group. In the FC line, the granulosa cells of the group fed ad libitum were more responsive to IGF-I at all doses than were those of the group fed a restricted diet; whereas in the GL line, the cells of the chickens fed a restricted diet were more responsive.

The effects of the combination of IGF-I at $25 \mathrm{ng} \mathrm{ml}^{-1}$ with various doses $\left(1,10\right.$ or $\left.25 \mathrm{ng} \mathrm{ml}^{-1}\right)$ of LH or FSH on DNA synthesis by cultured F3 granulosa cells of FCA and FCR groups are shown (Fig. 8). DNA synthesis in response to IGF-I $\left(25 \mathrm{ng} \mathrm{ml}^{-1}\right.$ ) alone was significantly higher in the granulosa cells of FCA than it was in the granulosa cells of FCR chickens. The addition of LH or FSH to IGF-I enhanced the stimulatory effect of IGF-I on DNA synthesis in a dosedependent manner, with significant effects at 10 and $25 \mathrm{ng}$ $\mathrm{ml}^{-1} \mathrm{LH}$ or FSH in the FCA group. In the FCR birds, the addition of LH at both 10 and $25 \mathrm{ng} \mathrm{ml}^{-1}$ with IGF-I also had significant effects on DNA synthesis but only $25 \mathrm{ng} \mathrm{FSH} \mathrm{ml}^{-1}$ had significant effects.

\section{Discussion}

The present study has demonstrated that the granulosa cells of the GL and FC lines respond differently to LH, FSH or IGF-I. The responsiveness of the cells obtained from the two lines differed for chickens fed ad libitum or restricted diets. The responsiveness to these hormones in terms of progesterone production and cell proliferation explained the differential in ovulation rate between the two lines.

Feed restriction reduced body weight, the number of yellow follicles, the incidence of atresia and improved egg production. Despite the similarity in body weights under ad libitum and restricted feeding, the two lines differed significantly in these parameters. The GL line had a significantly greater number of yellow follicles and more atresia than the FC line. Feed restriction significantly reduced numbers of follicles and the incidence of atresia. FC chickens fed ad libitum had fewer normal or atretic yellow follicles and diet restriction completely eradicated the incidence of atresia which led to a significant increase in egg production. This finding complements earlier results in similar chicken lines reported by Williams et al. (1986), Hocking and Whitehead (1990), Whitehead et al, (1990), Hocking et al. (1992) and Decuypere et al. (1993).

Low egg production in broiler breeders fed ad libitum has been attributed to multiple ovulation and atresia caused by the presence of a large number of follicles, two or three of

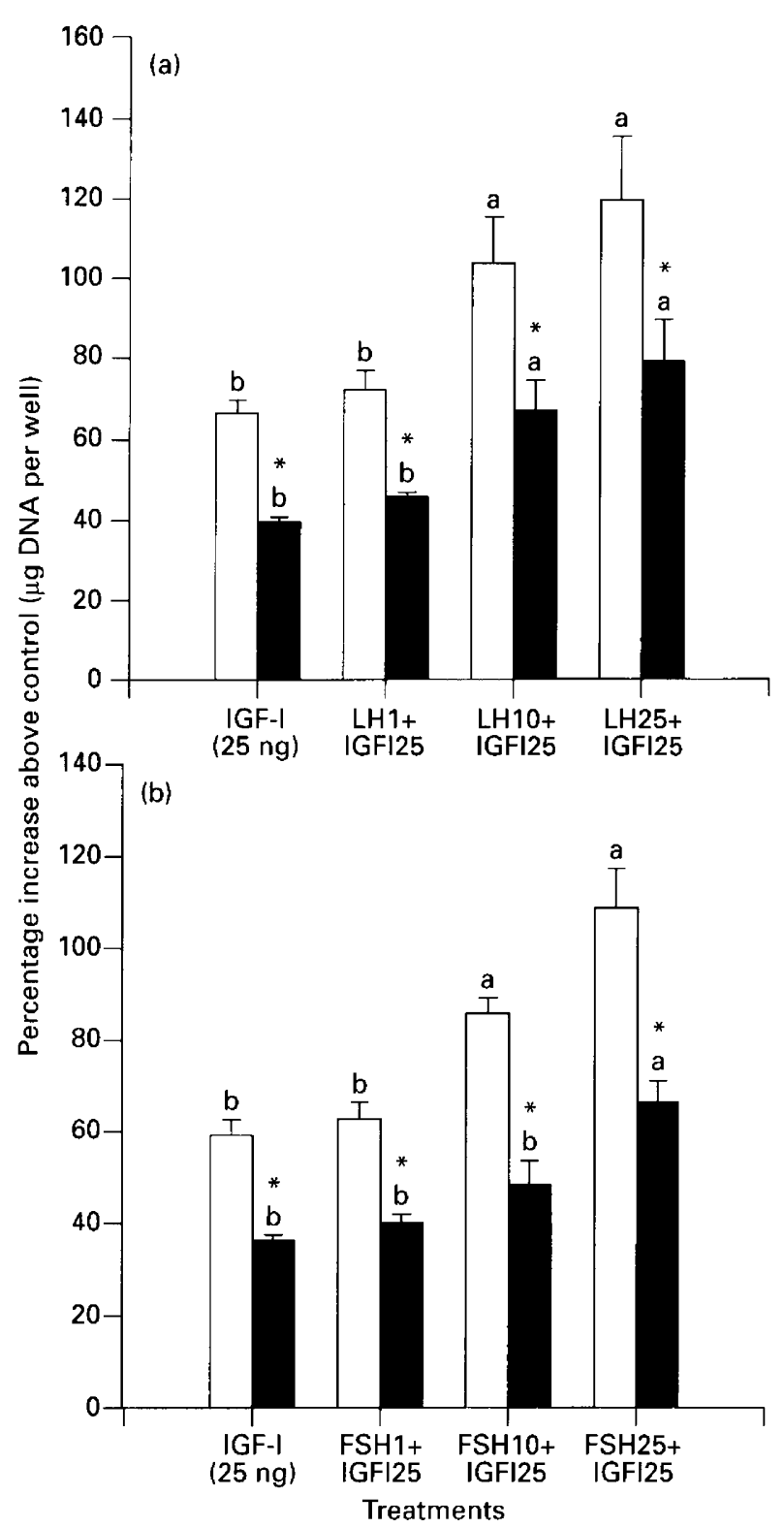

Fig. 8. Effect of insulin-like growth factor I (IGF-I; $25 \mathrm{ng} \mathrm{ml}^{-1}$ ) alone and in combination with (a) LH or (b) FSH $\left(1,10\right.$ or $\left.25 \mathrm{ng} \mathrm{m}^{-1}\right)$ on DNA synthesis by F3 granulosa cells from broiler breeder female chickens selected for food conversion efficiency fed ad libitum (FCA, $\square$ ) or restricted diet (FCR, $\square$ ). Cells were cultured in serum-free medium for $48 \mathrm{~h}$. Data are means \pm SEM of experiments repeated four times, each with four replicate wells. Data were analysed by ANOVA followed by a multiple range test. Significant differences $(P<0.05)$ between treatments within each line are denoted by different letters. Differences between birds fed ad libitum and restricted diets at each treatment were compared by Student's $t$ test and a significant difference is denoted by an asterisk, $P<0.05$.

which could be at a similar developmental stage (Hocking et al., 1987, 1989; Waddington and Hocking, 1993; Yu et al., 1992b). The results of the present study showed that all the birds fed ad libitum had internal ovulation, some of which could have resulted from multiple ovulation. Food 
restriction significantly reduced internal ovulation in the GL line and was absent in the FC line. Although the incidence of erratic and multiple ovulation or atresia can be reduced, little is known about the mechanisms that regulate their occurrence. Yu et al. (1992a) found that feed allowance changed follicular steroidogenesis in broiler breeder females, causing the largest (F1) and the second largest (F2) follicles to produce similar amounts of progesterone, which might have triggered an ovulation-inducing LH surge to release both follicles simultaneously. This hypothesis implies that developing follicles must maintain differential steroid production and, therefore, differential sensitivity to regulatory gonadotrophins. The present studies in vitro showed that responsiveness to $\mathrm{LH}$ and FSH differed between the GL and FC lines and between chickens fed ad libitum and restricted diets. The granulosa cells of both GLA and FCA birds showed similar responsiveness to $\mathrm{LH}$, with the F1, F2 and F3 cells producing similar amounts of progesterone. A major finding here was that feed restriction in both lines imposed a hierarchical order in the responsiveness of granulosa cells to $\mathrm{LH}$, although responsiveness to $\mathrm{LH}$ was significantly lower in FC birds fed a restricted diet. Whether this was a result of over-restriction in this line remains to be determined. While feed restriction significantly increased granulosa progesterone production in response to $\mathrm{FSH}$ in the GL line, it decreased it in the FC line. The decrease in the responsiveness of the cells of the FCR birds to both $\mathrm{LH}$ and FSH was unexpected. Whether this was a consequence of over-restriction also remains to be determined. However, restricted diet again imposed strict hierarchical order on the responsiveness of cells to FSH. These results clearly demonstrate that feed allowance changes the responsiveness of granulosa cells to LH and FSH and that ad libitum feeding disrupts the hierarchical endocrine order of follicles.

Previous studies have shown that growth factors are involved in the regulation of follicular development in mammals and birds (Adashi et al., 1985, 1992; Giudice, 1992; Onagbesan and Peddie, 1995). IGF-I and epidermal growth factor-transforming growth factor $\alpha$ and their receptors are expressed in avian granulosa cells where they regulate cell proliferation, steroidogenesis and modulate LH-FSH actions in the ovary (Roberts et al., 1994; Onagbesan and Peddie 1995; Armstrong and Hogg, 1996). Hocking et al. (1994) and Bruggeman et al. (1997) showed that plasma IGF-I concentrations during the laying period are higher in broiler breeder chickens fed a restricted diet than they are in birds fed ad libitum. This finding implies that IGF-I is important for maintaining a high rate of lay in chickens. The results show a close link between the gonadotrophins and IGF-I, indicating that IGF-I may be involved in the modulation of the effects of the gonadotrophins on steroidogenesis in the ovary of broiler breeder chickens. The combination of IGF-I with either LH or FSH enhanced the effectiveness of both gonadotrophins on progesterone production, leading to differential responsiveness of granulosa cells obtained from the different lines and feeding groups. Feed restriction significantly enhanced granulosa cell responsiveness to both LH and FSH, leading to increased progesterone production. This finding indicates that IGF-I is a major factor that regulates the sensitivity of ovarian granulosa cells to LH and
FSH in order to maintain a regulated maturation of the follicles. This mechanism ensures the ovulation of only the largest follicle that produces the highest progesterone. IGF-I had little enhancing effect on LH- or FSH-stimulated progesterone production in chickens fed ad libitum. In the GLA birds, the combined IGF-I-LH effect was not significantly higher than that of LH alone. The effect of both LH and IGF-I was similar in the three largest follicles. In vivo, this may lead to the ovulation of all three follicles in the absence of any modulating effect of IGF-I. A similar scenario can be advanced for the FCA birds, in which the effect of IGF-I was already high in one or two of the largest follicle cells. The addition of LH with IGF-I to the culture medium did not enhance the production of progesterone significantly by the F1 cells but did have some effect on the progesterone production by the F2 and F3 cells. Thus, the chances of one or two follicles ovulating simultaneously in vivo would be greatly increased. The results indicate that regulated differentiation of follicular granulosa cells in the preovulatory follicles of restricted birds involves an interaction between IGF-I and the gonadotrophins to maintain a regulated maturation. This interaction was absent in the granulosa of the chickens fed ad libitum.

The rate at which follicles advance to maturity must be regulated to maintain the normal hierarchy of ovarian follicles. Since the ovaries of the birds fed ad libitum contained more yellow follicles than the ovaries of birds fed a restricted diet, it follows that ad libitum feeding promotes the recruitment and rapid growth of yellow follicles. IGF-I promoted granulosa cell proliferation in culture and the rate of cell proliferation was higher in the GL line than in the FC line and was higher in the cells of birds fed ad libitum. There was no significant difference in the effect of IGF-I on granulosa cell proliferation when follicles of all lines had reached the F1 stage. However, at the F2 and F3 stages, the rates of cell proliferation in response to IGF-I differed significantly. The F2 and F3 cells of the GLA were not greatly responsive to IGF-I because, physiologically, they had reached the F1 stage and could be assumed to have had a much greater proliferation rate than their counterparts in the cells of birds fed a restricted diet. Both gonadotrophins (LH and FSH) significantly enhanced the effect of IGF-I on the proliferation of F3 cells from the FC line, particularly in the cells of birds fed ad libitum, providing further evidence that ad libitum feeding promotes the rapid growth of follicles by enhancing the effect of IGF-I and its interaction with gonadotrophins on cell proliferation. The GL line had a greater proliferation rate than did the FC line. The mechanism by which feed restriction exerts its effect in controlling follicular growth seemed to involve depressing the sensitivity of the cells to LH- or FSH-IGF-I-stimulated cell proliferation to maintain the hierarchical order of follicles. This finding is in agreement with previous suggestions by Armstrong (1994) and Hocking and McCormack (1995), who found fundamental differences between broilers and layers in the sensitivity of white follicles of different sizes to gonadotrophins. The present study also showed that progression in the yellow follicle hierarchy to maturation depended on the sensitivity of granulosa cells to LH or FSH in combination with IGF-I. 
Taken together, the results of the present study demonstrate that selection for growth must have affected factors that modulate changes in the sensitivity of follicles to gonadotrophins. However, these changes can be further modified at the ovary by feed allowance. The present data indicate that IGF-I is a major autocrine-paracrine factor in the ovary that is targeted both by genetic selection and feed allowance. However, it needs to be established whether IGFI production itself changes during follicular maturation or differs in follicles depending on the genetic line and the feeding regimen. It is possible that it is the signalling components that are altered. If this is the case, it could be of great significance in explaining the incidence of atresia since both IGF-I and epidermal growth factor-transforming growth factor $\alpha$ have been implicated in apoptosis (Tilly et al., 1991), a phenomenon that leads to atresia of follicles.

This research was supported by FKFO (G 0267.96) and OT-Project grants (OT/95/19). O. M. Onagbesan is a KUL fellow. The authors are grateful to $\mathrm{G}$. Nackaerts for technical support.

\section{References}

Adashi EY, Resnick CE, Svoboda ME and Van Wyk JJ (1985) Somatomedin C synergizes with follicle-stimulating hormone in the acquisition of progesterone biosynthetic capacity by cultured rat granulosa cells Endocrinology 116 2369-2375

Adashi EY, Resnick CE, Hurwitz A, Ricciallie E, Hernandez ER, Roberts CT, Leroith D and Rosenfeld R (1992) The intra-ovarian IGF system Growth Regulation 2 10-15

Armstrong DG (1994) The effect of LH, FSH and pregnant mares' serum gonadotrophin on ornithine decarboxylase activity in thecal and granulosa tissue during follicular growth and atresia in laying hens (Gallus domesticus) journal of Reproduction and Fertility 100 273-278

Armstrong DG and Hogg C (1996) Insulin-like growth factor-I (IGF-1), IGF-II and type-I IGF receptor gene expression in the ovary of the laying hen Journal of Reproduction and Fertility 106 101-106

Bruggeman V, Vanmontfort D, Renaville R, Portetelle D and Decuypere E (1997) The effect of food intake from two weeks of age to sexual maturity on plasma growth hormone, insulin-like growth factor-I, insulin-like growth factor-binding proteins, and thyroid hormones in female broiler breeder chickens General and Comparative Endocrinology 107 212-220

Decuypere E, Leenstra F, Huybrechts LM, Feng PY, Arnouts S, Herremans M and Nys M (1993) Selection for weight gain or feed conversion in broilers affects the progesterone production capacity of large follicles in the reproductive adult breeders British Poultry Science 34 543-552

Gilbert AB, Evans AY, Perry MM and Davidson MH (1977) A method for separating the granulosa cells, the basal lamina and the theca of the preovulatory ovarian follicle of the domestic fowl (Gallus domesticus) Journal of Reproduction and Fertility 50 179-181

Giudice LC (1992) Insulin-like growth factors and ovarian follicular development Endocrine Reviews 13 641-669

Hocking PM (1993) Effects of body weight at sexual maturity and the degree and age of restriction during rearing on the ovarian follicular hierarchy of broiler breeder females British Poultry Science 34 793-801

Hocking PM and McCormack HA (1995) Differential sensitivity of ovarian follicles to gonadotrophin stimulation in broiler and layer lines of domestic fowl Journal of Reproduction and Fertility 105 49-55

Hocking PM and Whitehead CC (1990) Relationship between body fatness, ovarian structure and reproduction in mature females from lines of genetically lean or fat broilers given different food allowance British Poultry Science 31 319-330

Hocking PM, Gilbert AB, Walker $\mathbf{M}$ and Waddington D (1987) Ovarian follicular structure of white Leghorns fed ad libitum and dwarf and normal birds fed ad libitum or restricted to point of lay British Poultry Science 28 493-506

Hocking PM, Waddington D, Walker MA and Gilbert AB (1989) Control of the development of the follicular hierarchy in broiler breeder pullets by food restriction during rearing British Poultry Science 30 161-174

Hocking PM, McCormack H and Whitehead CC (1992) Plasma estrogen and triglyceride concentrations and reproductive characteristics of broiler chickens after ten generations of selection at seven weeks of age for high or low plasma very low lipoprotein concentration British Poultry Science 33 1043-1056

Hocking PM, Bernard R, Wilkie RS and Goddard C (1994) Plasma growth hormone and insulin-like growth factor I (IGF-I) concentrations at the onset of lay in ad libitum and restricted broiler breeder fowl British Poultry Science $35299-308$

Jaap RG and Muir FV (1968) Erratic oviposition and egg defects in broilertype pullets Poultry Science $47417-423$

Johnson PA, Palmer SS and Bahr JM (1985) Hormone-stimulatable adenylyl cyclase and steroid concentration of follicles of the pregnant mares' serum gonadotrophin-treated hen Biology of Reproduction 32 828-833

Katanbaf MN, Dunnington EA and Siegel PB (1989) Restricted feeding in early and late-feathering chickens 2 . Reproductive responses Poultry Science $68352-358$

Labarca C and Paigen K (1980) A simple, rapid and sensitive DNA assay procedure Analytical Biochemistry 102 344-352

Leenstra FR and Pit R (1987) Fat deposition in a broiler sire strain 2. Comparison among lines selected for less abdominal fat, lower feed conversion ratio, and higher body weight after restriction and ad libitum feeding Poultry Science 66 193-202

Leenstra FR, Vereijken PFG and Pit R (1986) Fat deposition in a broiler sire strain 1. Phenotypic and genetic variation in, and correlations between, abdominal fat, body weight, and feed conversion Poultry Science 65 $1225-1235$

Onagbesan OM and Peddie MJ (1995) Effects of insulin-like growth factor I and interactions with transforming growth factor $\alpha$ and LH on proliferation of chicken granulosa cells and progesterone production Journal of Reproduction and Fertility 104 259-265

Peddie MJ, Onagbesan OM and Williams J (1994) Chicken granulosa cell proliferation and progesterone production: effects of EGF and thecal secretions General and Comparative Endocrinology 94 341-356

Roberts RD, Sharp PJ, Burt DW and Goddard C (1994) Insulin-like growth factor I in the ovary of the laying hen: gene expression and biological actions on granulosa and thecal cells General and Comparative Endocrinology 93 327-336

Tilly JL, Kowalski KI, Johnson AL and Hsueh AJW (1991) Ovarian follicular atresia and postovulatory regression are linked to apoptosis Endocrinology 129 2799-2801

Waddington D and Hocking PM (1993) Modification of intra-ovarian follicular distributions in broiler breeder hens by at libitum or restricted feeding British Poultry Science 34 777-784

Whitehead CC, Armstrong J and Herron KM (1990) The growth to maturity of lean and fat lines of broiler chickens given diets of different protein content: body composition, plasma lipoprotein concentration and initial egg production Animal Production 50 183-190

Williams J, Harvey S and Leclercq B (1986) Plasma levels of luteinizing hormone, growth hormone and estradiol from six weeks of age to sexual maturity in two lines of chickens selected for low or high abdominal fat content Poultry Science 65 1782-1786

Yu WM, Robinson FE, Charles RG and Weingardt R (1992a) Effect of feed allowance during rearing and breeding on female broiler breeders 2 . Ovarian morphology and production Poultry Science 71 1750-1761

Yu WM, Robinson FE and Etches RJ (1992b) Effect of feed allowance during rearing and breeding on female broiler breeders 3 . Ovarian steroidogenesis Poultry Science 71 1762-1767 